\title{
Cyclosporine in the management of esophageal lichen planus
}

\author{
M Chaklader BSc MD' 1 , C Morris-Larkin MD², W Gulliver MD FRCPC ${ }^{3}$, J McGrath BSc MD FRCPC ${ }^{4}$
}

\begin{abstract}
M Chaklader, C Morris-Larkin, W Gulliver, J McGrath. Cyclosporine in the management of esophageal lichen planus. Can J Gastroenterol 2009;23(10):686-688.
\end{abstract}

Lichen planus (LP) is an uncommon disorder of unknown etiology, mostly affecting patients in their fifth and sixth decade of life. It is believed to be an autoimmune process involving $\mathrm{T}$ cells directed against basal keratinocytes. It affects the skin, nails, oral pharynx and genitals. Esophageal involvement is quite rare and can cause strictures, ulcerations and squamous cell cancer. The present article describes the case of a 54-year-old woman who was referred for assessment of dysphagia that initially occurred with solids, which then progressed to soft foods but spared liquids. The patient reported a weight loss of $9.1 \mathrm{~kg}$. An esophagogastroduodenoscopy was performed and she was subsequently diagnosed with pill esophagitis. At the same time, she was also diagnosed with oral LP, with no involvement of the esophagus. She was treated with a proton pump inhibitor that resolved her gastrointestinal symptoms. The symptoms returned one year later and a repeat esophagogastroduodenoscopy revealed white plaques due to LP. She was treated with intermittent glucocorticoids. Diagnosis of esophageal LP is crucial for the proper treatment. Some patients may require systemic immunosuppression and mechanical dilation to prevent weight loss. Surveillance endoscopies should be performed to monitor for squamous cell cancer. Cyclosporine has been used for genital and oral LP, but the present case is the first in which it has been used successfully to treat esophageal LP.

Key Words: Civatte bodies; Cyclosporine; Dysphagia; Esophagus; Lichen planus; Squamous cell cancer

\section{La cyclosporine dans la prise en charge du lichen plan œsophagien}

Le lichen plan (LP) est un trouble peu fréquent à l'étiologie inconnue, qui touche surtout des patients dans la cinquantaine et la soixantaine. On pense qu'il s'agit d'un processus auto-immun mettant en cause les lymphocytes $\mathrm{T}$, qui attaquent les kératinocytes basales. Il touche la peau, les ongles, le pharynx oral et les organes génitaux. L'atteinte œesophagienne est plutôt rare et peut provoquer des étranglements, des ulcérations et un carcinome spinocellulaire. Le présent article expose le cas d'une femme de 54 ans qui avait été aiguillée pour subir une évaluation de dysphagie s'étant d'abord manifestée avec des solides, puis avait inclus les aliments mous, mais épargnait les liquides. La patiente a déclaré une perte de 9,1 kg. On lui a prescrit une œsophagogastroduodénoscopie, et elle a obtenu un diagnostic d'œsophagite piluleuse. Parallèlement, elle a reçu un diagnostic de LP oral, sans atteinte œosophagienne. Elle a été traitée au moyen d'inhibiteurs de la pompe à protons qui ont réglé ses symptômes gastrointestinaux. Les symptômes ont réapparu un an plus tard, et une nouvelle œsophagogastroduodénoscopie a révélé des plaques blanches imputables à un LP. Elle a reçu un traitement intermittent aux glucocorticoïdes. Le diagnostic de LP œsophagien est essentiel pour prescrire le bon traitement. Certains patients peuvent avoir besoin d'une immunosuppression systémique et d'une dilatation mécanique pour prévenir la perte de poids. Il faut procéder à des endoscopies de surveillance afin d'éviter l'apparition d'un cancer spinocellulaire. On a utilisé la cyclosporine pour traiter le LP génital et oral, mais il s'agit du premier cas où elle est utilisée avec succès dans le traitement du LP œsophagien.

\begin{abstract}
L ichen planus (LP) is an uncommon disorder of unknown etiology mostly affecting women in their fifth and sixth decade of life. It is believed to be an autoimmune process involving $\mathrm{T}$ cells directed against basal keratinocytes, similar to graft-versus-host disease. It affects the skin, nails, oral pharynx, vulva and penis. Esophageal LP was first described in 1982 by Al-Shihabi and Jackson (1). LP involving the esophagus, stomach and rectum are rare. Esophageal LP can cause strictures, ulcerations and squamous cell cancer. The present article describes a case of LP, including history, physical examination and endoscopic findings, as well as the different treatment options available.
\end{abstract}

\section{CASE PRESENTATION}

A 54-year-old woman with oral LP was referred for assessment of dysphagia at the Health Sciences Centre in St John's, Newfoundland, in May 2005. In 2004, the patient suffered from dysphagia with solids and was diagnosed with pill esophagitis by the community gastroenterologist. However, her dysphagia progressed to soft foods but spared liquids. She was finally referred to our centre. She had lost $9.1 \mathrm{~kg}$ of body weight and had no reflux symptoms. Her medical history was remarkable for oral and vaginal LP, and pill esophagitis. She consumed alcohol socially and was a nonsmoker. Her family history consisted of a maternal uncle and aunt with colon cancer in their sixth decade of life. Her medications included tacrolimus $0.1 \%$ ointment twice daily and esomeprazole $40 \mathrm{mg}$ daily.

\section{First endoscopy}

Her first endoscopy showed white plaques in the esophagus (Figures 1 and 2), which was quite narrow with strictures (Figure 3); therefore, advancing an adult endoscope was not possible. Candida was visible with the plaques. A biopsy revealed a dense lichenoid inflammatory infiltrate and candida yeast overgrowth (Figure 4).

${ }^{1}$ Department of Medicine; ${ }^{2}$ Division of Pathology; ${ }^{3}$ Division of Dermatology; ${ }^{4}$ Division of Gastroenterology, Memorial University of Newfoundland, St John's, Newfoundland

Correspondence: Dr Mohsina Chaklader, University of Alberta, 1-10 Zeidler Ledcor Centre, 130 University Campus, Edmonton, Alberta

T6G 2X8. Telephone 780-906-9775, fax 780-492-1600, e-mail mchak023@alumni.uottawa.ca

Received for publication July 24, 2008. Accepted July 28, 2008 


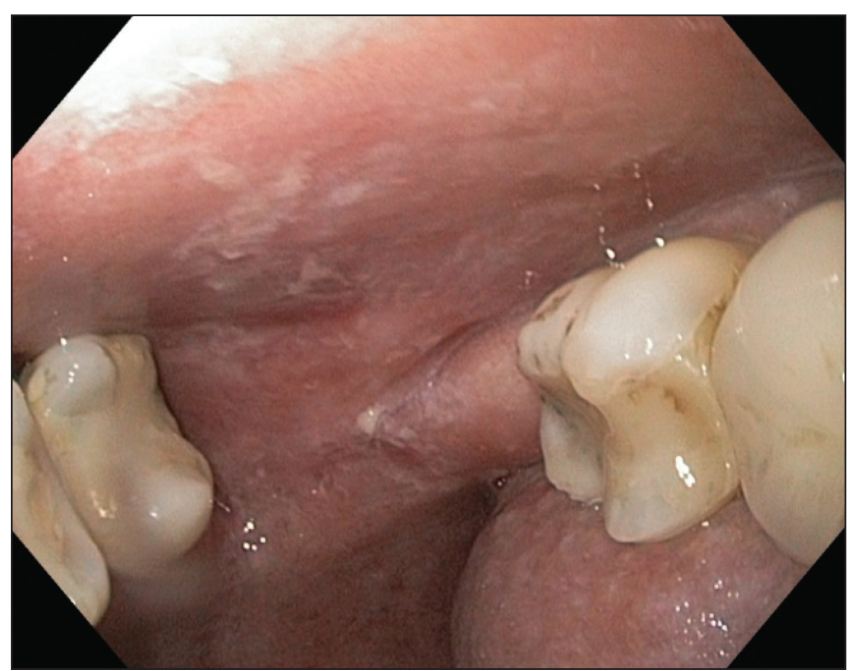

Figure 1) Oral mucosal lesions, consistent with lichen planus

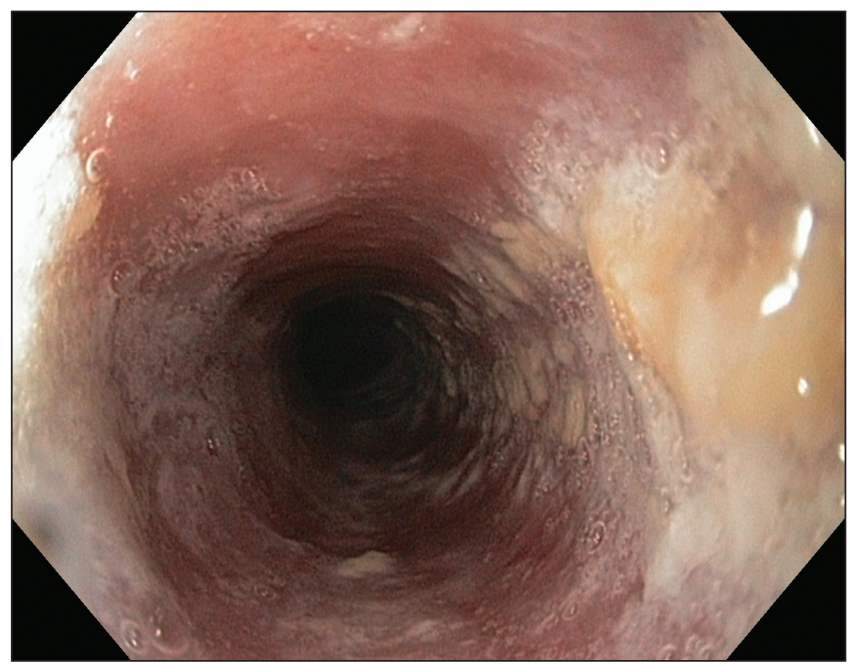

Figure 2) Esophageal lichen planus with Candida species yeast infection

\section{Second endoscopy}

She was treated for candida esophagitis and underwent endoscopy three months later. Endoscopy was performed with a pediatric gastroscope under fluoroscopy and revealed strictures with white plaques and friable mucosa.

\section{REVIEW}

LP is a 'silent' disease until the patient develops strictures and experiences dysphagia. The following will describe the usual findings involved in LP esophagitis.

\section{History and physical examination}

Patients are usually asymptomatic; therefore, the incidence of esophageal LP is underestimated. Some patients may experience dysphagia due to strictures. Esophageal LP can also affect individuals with cutaneous LP - present as flat-topped, pruritic and violaceous papules or plaques in the flexural region of the arms, legs and wrists. Esophageal LP has a strong correlation to oral LP. Patients do not usually display symptoms of reflux disease. However, they are frequently mistaken to have gastroesophageal reflux disease and are treated without relief.

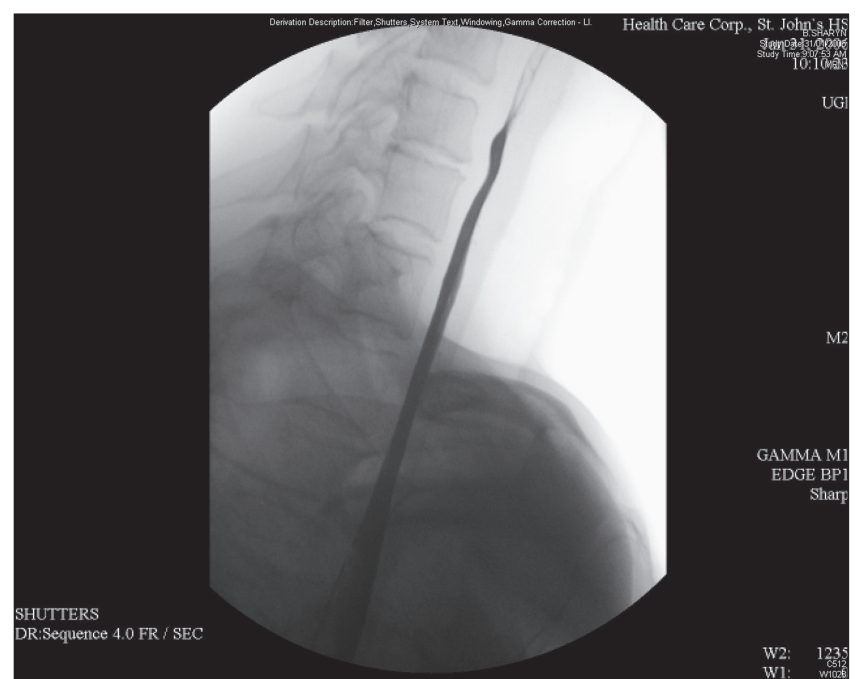

Figure 3) Barium swallow showing decreased luminal calibre throughout the entire esophagus

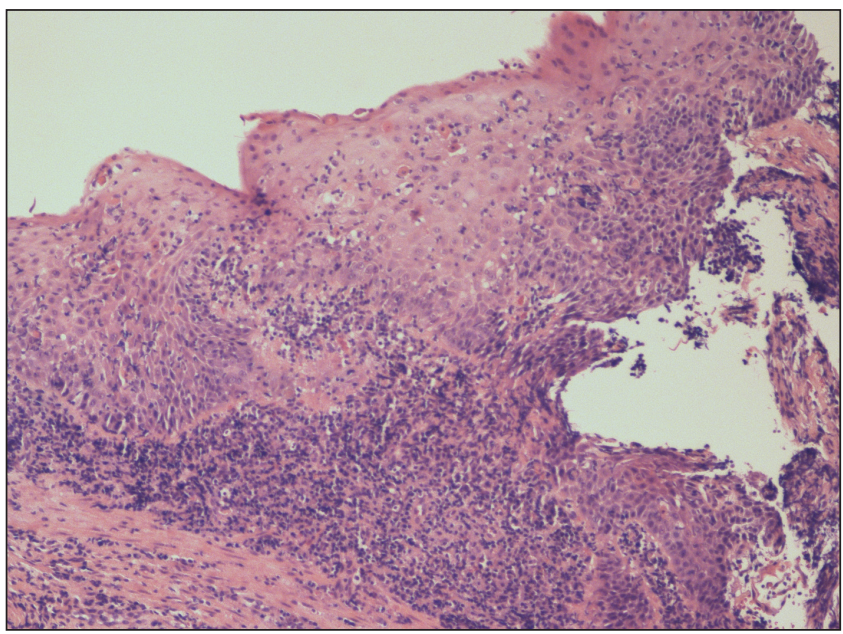

Figure 4) Dense lichenoid inflammatory infiltrate underneath the lamina propria due to lichen planus. Civatte bodies are eosinophilic hyaline spherical bodies that are seen beneath the epidermis, particularly in lichen planus

\section{Endoscopic findings}

Endoscopy reveals proximal stricture formation, ulcers, granulation tissue and inflammation in two-thirds of the esophagus. In addition, white, desquamating membranes with underlying friable mucosa can be found (Figure 5). The esophageal epithelium is usually atrophic and shows parakeratosis.

\section{DISCUSSION}

Early and accurate diagnosis of esophageal LP is crucial because there is a potential risk for malignant transformation. Early diagnosis also helps initiate appropriate treatment and saves the patient from unnecessary dilation and weight loss. According to Shenfine and Preston (2), the risk of malignant transformation in patients with oral LP is $1 \%$ to $3 \%$, and $0.5 \%$ to $1 \%$ according to Abraham et al (3). The actual malignant risk of esophageal LP is unknown and may mirror that of oral LP. To date, only three cases of squamous cell carcinoma arising from esophageal LP have been reported $(4,5)$. Esophageal LP is 


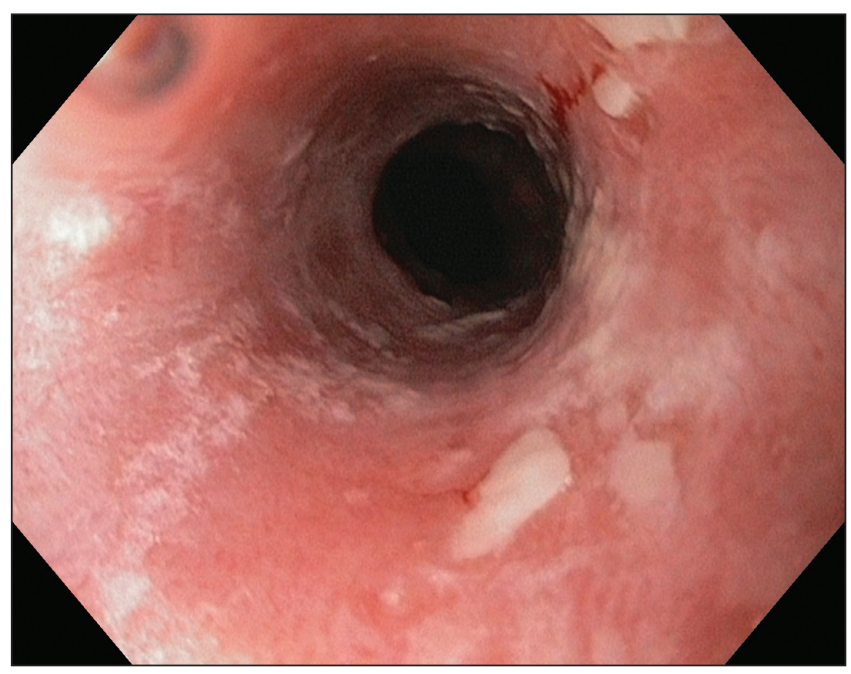

Figure 5) Esophageal lichen planus with friable mucosa

under-reported because the symptoms are not always present. Dysphagia is common in symptomatic patients. LP tends to present in the proximal to mid esophagus. Because patients become uncomfortable when the endoscope approaches the epiglottis, there is a tendency to advance the endoscope quickly and miss oropharyngeal lesions, even by expert endoscopists.

\section{Treatment}

Steroid therapy is the key treatment. Dilation of the strictures is believed to cause more damage via the Koebner phenomenon. However, if the patient is symptomatic and steroids do not act quickly enough, dilation can be performed. Retinoic acid has also been recommended for esophageal LP. Tacrolimus has been shown to be beneficial for the treatment of esophageal LP (6). It is also used as a topical agent for the treatment of genital and oral LP. Cyclosporine has been used to treat genital LP (7). Antibacterial agents such as dapsone and immunosuppressants such as azathioprine have been used to treat only intractable cases of mucocutaneous LP $(8,9)$. Unlike oral LP, esophageal LP cannot be treated with topical agents. Systemic agents are needed and relapse can occur once these agents are discontinued

\section{CONCLUSION}

Previous studies have shown that oral cyclosporine can be used successfully to treat oral LP (10). The present case is the first in which cyclosporine has been used successfully to treat esophageal LP.

\section{REFERENCES}

1. Al-Shihabi BM, Jackson JM. Dysphagia due to pharyngeal and oesophageal lichen planus. J Laryngol Otol 1982;96:567-71.

2. Shenfine J, Preston SR. Lichen Planus in the oesophagus: Are we missing something? Eur J Gastroenterol Hepatol 2006;18:1043-5.

3. Abraham SC, Ravich WJ, Anhalt GJ, Yardley JH, Wu T.

Esophageal lichen planus. Am J Surg Pathol 2000;12:1678-82.

4. Schwartz MP, Sigurdsson V, Vreuls W, Lubbert PHW, Smout AJ.

Two siblings with lichen planus and squamous cell carcinoma of the oesophagus. Eur J Gastroenterol Hepatol 2006;18:1111-5.

5. Calabrese C, Fabbri A, Benni M, et al. Squamous cell carcinoma arising in esophageal lichen planus. Gastrointest Endosc 2003;57:596-9.

6. Keate RF, Williams JW, Connolly SM. Lichen planus esophagitis: Report of three patients treated with oral tacrolimus or intraesophageal corticosteroid injections or both. Dis Esophagus 2003;16:47-53.

7. Bobadilla J, van der Hulst RW, ten Kate FJ, Tytgat GN. Esophageal lichen planus. Gastrointest Endosc 1999;50:268-71.

8. Kumar B, Kaur I, Bhattacharya M. Dapsone in Lichen planus. Acta Derm Venereal 1994;74:334. (Lett)

9. Klein L R, Callen J P. Azathioprine: Effective steroid-sparing therapy for generalized Lichen planus. South Med J 1992;85:198-201.

10. Eisen D, Ellis CN, Duell EA, Griffiths CE, Voorhees JJ. Effect of topical cyclosporine rise on oral lichen planus. A double-blind analysis. 1990;323:290-4. 


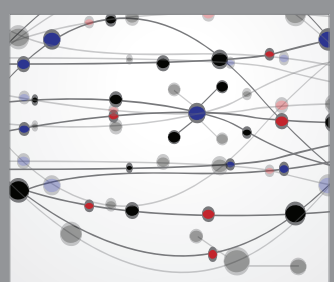

The Scientific World Journal
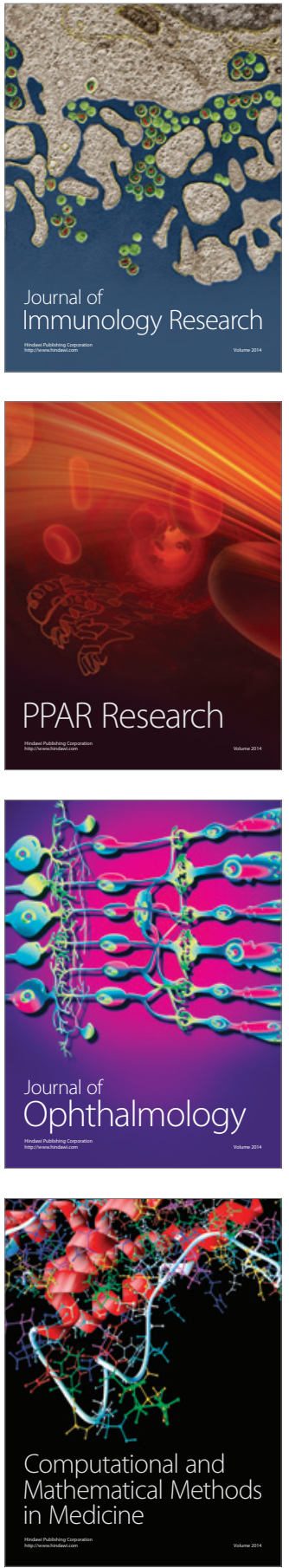

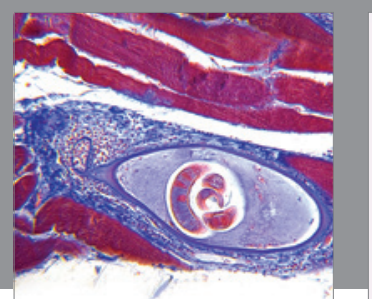

Gastroenterology Research and Practice

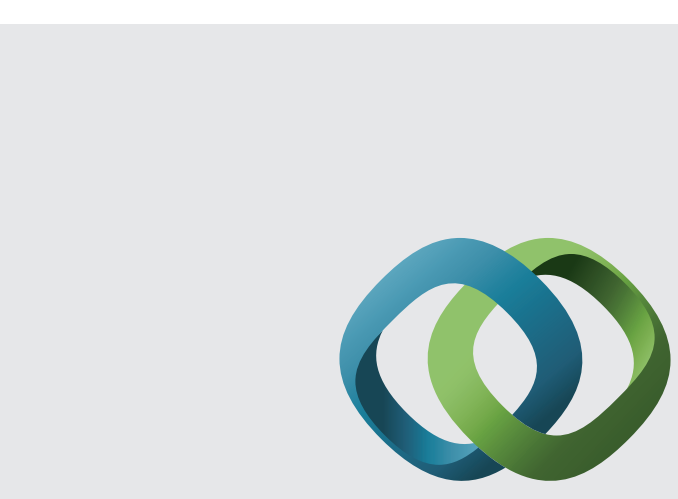

\section{Hindawi}

Submit your manuscripts at

http://www.hindawi.com
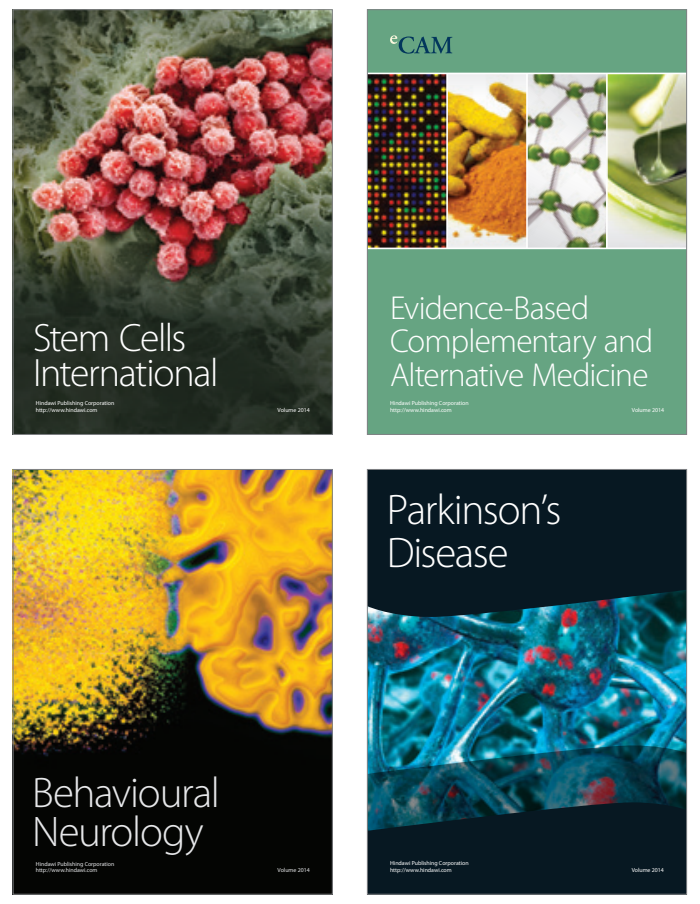
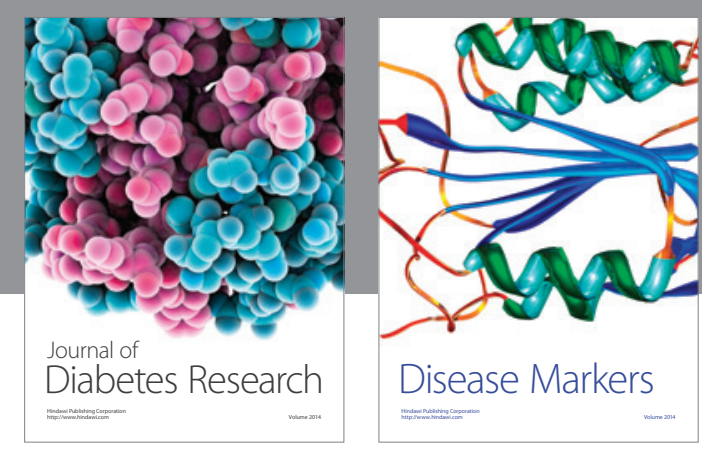

Disease Markers
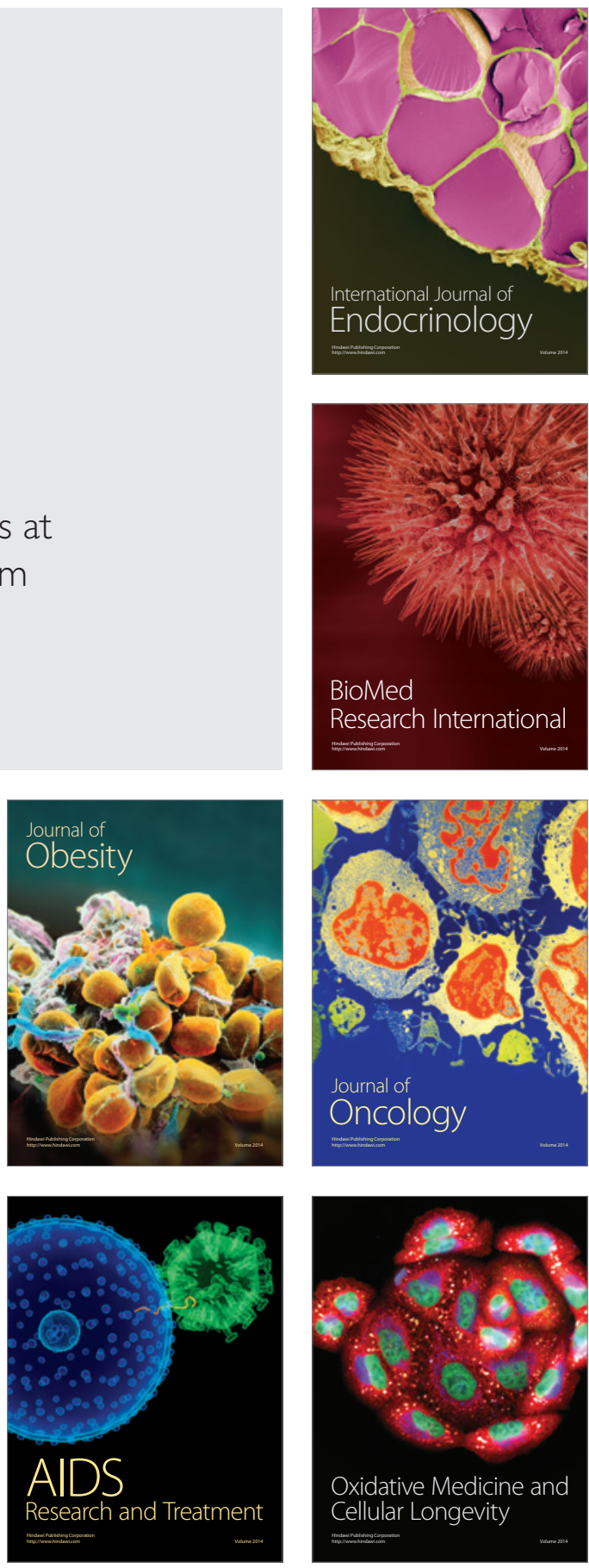